\title{
Effect of Plant Density on Morphologic Characteristics Related to Lodging and Yield Components in Different Rice Varieties (Oriza Sativa L.)
}

\author{
Yadi Reza \\ Department of Agriculture, Payam Nour University \\ Boushehr branch, Boushehr, Iran \\ E-mail: Reza_yadi2007@yahoo.com \\ Siavoshi Morteza (Corresponding author) \\ Ph.d Student of Botany Department at Fergusson College, Pune, India \\ Tel: 91-989-098-7811_E-mail: Morteza_siavoshi@yahoo.com \\ Mobasser Hamidreza \\ Faculty Member of Azad University at Ghaemshahr, Iran \\ E-mail: Hamidreza_mobasser@yahoo.com \\ Dastan Salman \& Nasiri Alireza \\ Department of Agronomy, Science and Research branch \\ Islamic Azad University, Tehran, Iran \\ E-mail: Sdastan@srbiau.ac.ir; a.nasiri1362@gmail.com \\ Accepted: March 31, $2011 \quad$ Online Published: December 1, 2011 \\ URL: http://dx.doi.org/10.5539/jas.v4n1p31
}

Received: March 14, 2011

doi:10.5539/jas.v4n1p31

\begin{abstract}
In order to study the effects of plant density on agronomical and morphologic characteristics which are related to the lodging in rice varieties, an experiment was carried out in 2008 in split plot in randomized complete block design based on 4 replications in Iran. In this experiment, five rice varieties of Tarom (Local, Hashemi, Dilamani, Langhrodi and Sangh) were chosen as main factors and three plant density levels (40, 80, and 120 bushes per $\mathrm{m}^{2}$ ) as sub-factors. The results showed that Langhrodi Tarom had minimum total number of spikelets and number of hollow spikelets per panicle and minimum tiller per bush and number of panicles per $\mathrm{m}^{2}$ had seen sequentially in Local Tarom and Sangh Tarom. The shortest length of first, second, and third inter-nodes, longest diagonal of the third inter-node and minimum plant height obtained for Langhrodi Tarom. Number of node and length of first, second and third inter-node and diagonal of the forth inter-node and Stem tension to lodging in third and forth inter-node decreased as plant density increased. Minimum lodging index of the third and forth inter-node came out at 80 bushes per $\mathrm{m}^{2}$. Interaction effects in plant density had significant effects on all parameters except panicle number per $\mathrm{m}^{2}$.
\end{abstract}

Keywords: Rice, Plant-density, Bending movement, Lodging index

\section{Introduction}

Lodging is one of the important environmental factors for limiting of having the maximum grain yield in cereal such as rice (Setter et al., 1997). In plant density with destruction of normal structure of canopy, the photosynthesis capability and dry-material production is decreased (Hitaka and Kobayashi, 1961). Lodging prevents the water transition, nutrition and assimilation through xylem and phloem and consequently, reduces the fill of the seeds (Kashikawa et al., 2005). Increasing of the lodging humidity in a canopy, prepares the conditions of illness expanding and growth of fungus, which is the limiting factor for constructing and qualification of the seeds (Kono, 1995).

In those plants which have faced lodging, it is possible that some kinds of seeds, that have a weak dormancy, can germinate on the panicle of main bush. But lodging decreases the qualitative and quantitative of the seeds. Therefore, lodging brings problems in harvest, increases the time of seed-dryness and finally increases the expenses of the production (Hoshikawa et al., 1990). Expanding of short-height rice verities and wheat in 1960s by Sd-1 gene brought a lot of success for improvement of insistency against the lodging and increasing of grain yield potential (Chandler, 1969). The reduction of plant height with Sd-1 gene reduced the effects of up parts of the plant on lower parts and also it improved the insistency against the lodging. The recent studies revealed that 
grain yield does not change because short-height of the rice limits the canopy photosynthesis and biomass production (Kuroda et al., 1989).

Flintham et al. (1997) indicated that plant height for maximum photosynthesis capacity in canopy should be suitable and grain yield can reduce with reduction of plant height under less than proper level, But Ookawa et al. (1992) reported that the plant height is not a significant and necessary factor for identifying of resistance rate against the lodging and the lodging ability is diverse among varieties with same plant height (Ookawa and Ishihara, 1992). Among of morphological characteristics, there is a connection between the weight and diagonal of the stem with the resistance against the lodging and stem stability with brokenness (Yoshinaga, 2005). The husk of leaf and length of below inter-node of the stem are main characters for recognizing of the stem consistency (Chang and Vergara, 1972). The husk of the leaf helps 30-60\% the resistance of above ground parts brokenness (Chang, 1964). Lodging resistance in below inter-nodes is twice more than the leaf-husk and thrice more than the middle inter-node (Ookawa and Ishihara, 1992).

The resistance-pressure is a lodging index which has a positive correspondence with the thickness of the stem and the weight of the roots under the deep soil (Terashima et al., 1994). Maximum use of necessary factors for the growth of the plant occurs when the canopy enters maximum pressure to the all production factors; consequently, because of canopy competition among the bushes of this canopy goes under extreme stress (Dunald and Dilly, 1982). Hence, when the fertility of the soil is abundant we should have consideration to the number of bush per square-unit in comparison with the weakness of the soil (tang and Oingfa, 2000). Whereas the economic yield includes only the grain yield, then we have to choose an proper planting distance and beyond that because of high planting-density, photosynthesis material is consumed for the growth and respiration of the plant rather than growth of the grain (Hadji, 2002).

Baloch et al. (2002) found that the reason of rice grain yield enhancement under high plant density was due to the increase of the panicles in $\mathrm{M}^{2}$. But at the same time the number of tillers and effective tiller in bush showed significant reduction (Baloch et al., 2002). Therefore, with increasing of planting-density, in spite of the reduction of total number of tiller and effective tiller per bush, because of the increasing of the stem per square meter; consequently, number of panicle in $\mathrm{M}^{2}$ and grain yield were increased. Also plant height in various genotypes of rice decreased by the increasing plant density (Mobasser et al., 2007). According to the importance of plant density on yield and yield components and also extreme role of lodging on agronomical characteristics of the rice an experiment was conducted for study effects of plant density on the morphological and yield components characteristics of lodging in 5 varieties of rice.

\section{Materials and Methods}

In order to consider effect of plant density on agronomical characteristics, indices of lodging resistance and rice varieties yield an experiment was done during the year 2009 in Babol, Iran. This place has $36^{\circ}, 33^{\prime} \mathrm{N}$ and $53^{\circ} \mathrm{E}$ and 14 meters above the sea level. Rainfall and evaporation was $79.9 \mathrm{~cm}$. Maximum rains were $42 \mathrm{~mm}$ in (Aug-Sep) and minimum rain in (May-Jun) was about $0.3 \mathrm{~mm}$. The soil of field was clay-loam. The results of soil analysis were as follows:

Depth $=0-30 \mathrm{~cm}$

$\mathrm{pH}=7.94$

Electric conductivity $=0.8$ mille-mousse

$\mathrm{OM}=3.38$

Available $\mathrm{P}=23 \mathrm{ppm}$

Available $\mathrm{K}=100 \mathrm{ppm}$

Total Nitrogen $=22 \%$

This experiment was done as split plot in randomized complete blocks design based 4 replications. Rice variety was arranged as main factor in five varieties which are famous in Iran (Local Tarom, Hashemi Tarom, Deylami Tarom, Langhrodi Tarom, and Sangh Tarom) and plant density was as sub-factor in three levels (40, 80, and 120 bushes in $\mathrm{M}^{2}$ respectively). Rice was also the previous cultivated product. For planting of the rice at the end of February the field was plowed and at the middle of May was done the complete plow operation, which includes vernal plow, trowel and levelling. Before transplanting, the field divided into four replications and in any repetition it divided into 15 plots, $2 \times 5 \mathrm{~m}^{2}$.

$150 \mathrm{~kg} / \mathrm{ha}$ Urea was supplemented as a source of urea to the main plant in three times (in time of transplantation, in time of initiative panicle, and in time of complete panicle). Also Phosphoric fertilizer in form of triple super-phosphate and potassium fertilizer in form of Sulphate-potassium was used about 110 and $100 \mathrm{~kg} / \mathrm{ha}$ respectively. When the seedlings have gotten $25 \mathrm{~cm}$ of height, seedlings were uprooted then were transplanted in main field according to plant-density treatment with various plant-dressing. All operations like irrigation, weeds control, plant illnesses controlling, pests controlling were done during the growth process with chemical 
components.

During the growth time, following characteristics was measured randomly from each plot.

1) Plant height was measured from 12 bushes in middle of each plot.

2) Number of panicle per $\mathrm{M}^{2}$ was numerated in the middle of each plot.

3) Total number of tiller was numerated per bush in each plot from 12 bushes.

4) Total number of spikelet per panicle and number of hollow spikelet per panicle were counted from 15 panicles in each plot.

5) Grain yield and biomass were harvested from $4 \mathrm{M}^{2}$ from the middle of the plot with $12 \%$ humidity.

6) Also harvest index has come from grain yield / biologic yield.

7) Weight of 1000-seed by choosing and numerating of 10 panicles in hundred numbers (in $12 \%$ humidity).

For measuring characteristics morphological (30 days after panicle initiation) from each plot 4 bushes and from per bush 3 stems were chosen and then these characteristics were measuring:

1) Length of inter-node 1, 2, 3 and 4 (numeration of inter-node is from up to down of the stem) were measured in $\mathrm{cm}$.

2) Diagonal of $3^{\text {rd }}$ and $4^{\text {th }}$ inter-node was measured by calliper in millimetre.

3) Stem tension to lodging in $3^{\text {rd }}$ and $4^{\text {th }}$ inter-node of any stem was measured as below:

Stem tension to lodging of the $3^{\text {rd }}$ inter-node $=$ length of the plant from the lowest node of $3^{\text {rd }}$ inter-node up to the panicle $\times$ the wet weight of same part.

Stem tension to lodging of $4^{\text {th }}$ inter-node $=$ length of the plant from the lowest node of $4^{\text {th }}$ inter-node up to the panicle $\times$ the wet weight of the same part.

4) Lodging resistance was calculated by Prost rate and according to the necessary power for breaking of $3^{\text {rd }}$ and $4^{\text {th }}$ inter-nodes of the stem.

Lodging index of $3^{\text {rd }}$ and $4^{\text {th }}$ inter-nodes brought out by these formulas:

(Lodging index of $3^{\text {rd }}$ inter-node) $L I N 3=\frac{\text { Stem tension to lodging of } 3^{\text {rd }} \text { inter-node }}{\text {. }}$

Lodging resistance of $3^{\text {rd }}$ inter-node

(Lodging index of $4^{\text {th }}$ inter-node) $L I N 4=\underline{\text { Stem tension to lodging of } 4^{\text {th }} \text { inter-node }}$

Lodging resistance of $4^{\text {th }}$ inter-node

Data analyzed by MSTATC statistical software and Averages comparison were calculated by Duncan's multiple range tests in a $5 \%$ probability level.

\section{Results and Discussion}

3.1 The effect of variety and interaction effect of variety $\times$ plant density over morphological treats and yield components

As it is seen in the diagram 1, plant height was significant under the effect of variety and interaction effect of variety $\times$ plant density in $1 \%$ probability level. The max and min plant height came out, sequentially, local Tarom and langhrodi Tarom. Also in table 2 it is seen that with increasing of plant density from 40 to 120 bushes in any $\mathrm{m}^{2}$ plant height had decrease $1 / 42 \%$ but it was nonsignificantly. Max plant height was $(168 / 5 \mathrm{~cm})$ under the interaction effect of variety $\times$ planting-density, for local Tarom with 40 bushes in $\mathrm{M}^{2}$ and min plant height was $(132 / 5 \mathrm{~cm})$ for Langhrodi Tarom with 120 bushes in $\mathrm{M}^{2}$ (Diagram1). Number of tiller per bush was significant under effect of variety, plant density and their interaction effects in 1\% probability level (table 1 ). In table 2 we can see that the minimum number of tiller per bush is for local Tarom, maximum of that is for Hashemi Tarom and Dilamani Tarom. Maximum total number of tiller per bush was under the various plant density for 40 bushes per $\mathrm{M}^{2}$ and by increasing of plant density up to 80 and 120 bushes in $\mathrm{M}^{2}$ this number was reduced. Maximum total number of tiller per bush under the interaction effects of variety $\times$ plant density was for Dilamani Tarom with 40 bushes per $\mathrm{M}^{2}$ and minimum of that was for Langhrodi Tarom with 120 bushes per $\mathrm{M}^{2}$ (Table 3).

Total number of spikelet and hollow spikelet per panicle had not a significantly difference under the effect of variety and interaction variety effects $\times$ plant density in $1 \%$ probability level (Table 1 ). Minimum total number of spikelet and hollow spikelet per panicle came to Langhrodi Tarom. Maximum hollow spikelet was seen in Sangh Tarom (Table 2). Sangh Tarom had maximum number of hollow spikelet per panicle, minimum number of panicle per $\mathrm{M}^{2}$ and consequently it had minimum grain yield. It is clear from the table 1 that the number of panicle per $\mathrm{M}^{2}$ was significant under the effect of variety and plant density in a $1 \%$ probability level, as the maximum number of the panicle was for Dilamani Tarom, Langhrodi Tarom and minimum of that was for Sangh Tarom and also minimum number of panicle per $\mathrm{M}^{2}$ was under the effect of various plant density in 40 bushes per $\mathrm{M}^{2}$. By increasing of the plant density up to 80 and 120 bushes per $\mathrm{M}^{2}$ it increases into $9 / 2$ and $18 / 5 \%$ 
(table 2). Number of the panicle per $\mathrm{M}^{2}$ by increasing of the density from 40 into 120 bushes per $\mathrm{M}^{2}$ under the interaction effect of variety $\times$ plant density were increasing, local Tarom, Hashemi Tarom, Dilamani Tarom, Langhrodi Tarom and Sangh Tarom (table 3). Variety and interaction effects of variety $\times$ plant density were significant on the weight of 1000 -grain in a $1 \%$ probability level (table 1). Minimum weight of 1000-grain was for Hashemi Tarom and it was not significant for other varieties. Also, there was not any difference under various plant density (table 2). As it is clear from table 1, grain yield was significant under effect by variety, plant density, and their interaction effects in 1\% probability level. Maximum grain yield was for Langhrodi Tarom, for local Tarom and minimum of it was for Hashemi Tarom. It also under the various plant density (40, 80, and 120 bushes per $\mathrm{m}^{2}$ ) has shown for Langhrodi Tarom, local Tarom and Hashemi Tarom (table 2). Maximum grain yield under the interaction effect of variety $\times$ plant density was for local Tarom (40 bushes per $\mathrm{m}^{2}$ ) and minimum of it was for Hashemi Tarom under the density of 40, 120 bushes per $\mathrm{m}^{2}$ (table 3 ).

Mobasser et al. (2007) concluded that length of growth period, length of panicle, percent of full spikelet and weight of 1000-grain was not affected by planting-density. By increasing of plant density in various genotypes of rice, in spite of the deduction of total number of tiller and effective tiller per bush, because of increasing of stem number and number of panicle increased per $\mathrm{M}^{2}$ (Mobasser et al., 2007).

Usually in rice plant, plant height deduced when it has a limitations on assimilation of food materials, by increasing of plant density (Vojdani, 2006; Mobasser et al., 2007).

\subsection{The effect of variety, plant density and their interaction on inter-nodes}

As it is seen in table 4 , the length of $1^{\text {st }}$ and $2^{\text {nd }}$ inter-nodes was experimented from statistical point of view under the effect of variety, plant density and their interaction effects in $1 \%$ probability level and the variety in $1 \%$ probability level had significantly effect on the length of $3^{\text {rd }}$ and $4^{\text {th }}$ inter-nodes, but plant density had only significantly effect on the length of $3^{\text {rd }}$ inter-node. Interaction effects of the variety $\times$ plant density had significantly effect on $3^{\text {rd }}$ inter-node in $5 \%$ probability level and on $4^{\text {th }}$ inter-node in $1 \%$ probability level. Maximum length of $1^{\text {st }}$ and $2^{\text {nd }}$ is seen in Hashemi Tarom and shortest length of $4^{\text {th }}$ inter-node also is seen in Hashemi Tarom. Minimum length of $2^{\text {nd }}$ and $3^{\text {rd }}$ inter-node had seen in Langhrodi Tarom.

In table 5 can see that by increasing of plant density the length of $1^{\text {st }}, 2^{\text {nd }}$, and $3^{\text {rd }}$ inter-nodes are decreasing significantly and by increasing of the plant density up to 120 bushes per $\mathrm{m}^{2}$, the length of these inter-nodes decreased, but the length of $4^{\text {th }}$ inter-node was not affected by the plant density. Maximum length of $1^{\text {st }}$ and $2^{\text {nd }}$ inter-nodes under the interaction effects of variety $\times$ plant density for Hashemi Tarom with 40 bushes per $\mathrm{m}^{2}$ and minimum of it was for Langhrodi Tarom with 80 bushes per $\mathrm{m}^{2}$ (table 6). In table 6 also can see that the maximum length of $3^{\text {rd }}$ inter-node was for local Tarom with 40 bushes per $\mathrm{m}^{2}$ and minimum of it was for Langhrodi Tarom with 120 bushes per $\mathrm{m}^{2}$. In local Tarom, Hashemi Tarom, and Langhrodi Tarom variety, by increasing of plant density the length of $3^{\text {rd }}$ inter-node has had a decreasing rate (table 6). Minimum lengths of 3 rd inter-node were for Dilamani Tarom and Sangh Tarom with 80 bushes per $\mathrm{m}^{2}$. Maximum length of $4^{\text {th }}$ inter-node was for local Tarom with 40 bushes per $\mathrm{m}^{2}$ and minimum of it was for Langhrodi Tarom with 120 bushes per $\mathrm{m}^{2}$ (table 6 ).

The number of inter-nodes from statistical point of view under the effect of variety and plant density did not show a significantly difference (table 4), as the minimum number of inter-node were for Langhrodi Tarom and Sangh Tarom. Also, the number of inter-nodes by increasing of plant density from 40 bushes per $\mathrm{m}^{2}$ into 120 bushes per $\mathrm{m}^{2}$ has had 5/7\% deduction (table 5). variety and interaction effect of variety $\times$ plant density had significantly effect on the diagonal of $3^{\text {rd }}$ and $4^{\text {th }}$ inter-nodes in $1 \%$ probability level and the effect of plant density had significantly affect on the diagonal of the $3^{\text {rd }}$ and $4^{\text {th }}$ inter-nodes in $5 \%$ and $1 \%$ probability level (table 4), as it is seen in table 5, maximum and minimum diagonal of $3^{\text {rd }}$ inter-node were for Langhrodi Tarom and local Tarom respectively and also, maximum and minimum diagonal of $4^{\text {th }}$ inter-node were for Sangh Tarom and Dilamani Tarom respectively. Minimum diagonal of $3^{\text {rd }}$ inter-node comes under the plant density of 80 bushes per $\mathrm{m}^{2}$, but the diagonal of the $4^{\text {th }}$ inter-node by increasing of plant density from 40 bushes into 120 bushes per $\mathrm{m}^{2}$ deduced.

As mentioned in the results, shortest length of $1^{\text {st }}, 2^{\text {nd }}$ and $3^{\text {rd }}$ inter-nodes was for langhrodi tarom but in $4^{\text {th }}$ inter-node was for Hashemi Tarom and minimum number of inter-nodes was for Langhrodi tarom and maximum diagonal of $3^{\text {rd }}$ inter-node and minimum plant height was belong to Langhrodi Tarom and because of this case, maximum Lodging resistance of $3^{\text {rd }}$ and $4^{\text {th }}$ inter-nodes and minimum lodging index of $3^{\text {rd }}$ and $4^{\text {th }}$ inter-nodes was also belong to this variety and for this reason Langhrodi Tarom had better and easy transition of photosynthesis materials to the seeds, consequently it had minimum number of hollow spikelet, maximum number of panicle, maximum grain yield and harvest index.

Maximum diagonal of $3^{\text {rd }}$ inert-node under the interaction effects of variety $\times$ plant density was for Langhrodi Tarom with 80 bushes per $\mathrm{m}^{2}$ and minimum of it was for local Tarom with 80 bushes per $\mathrm{m}^{2}$ and for Dilamani Tarom was with same bushes (table 6). Maximum diagonal of $4^{\text {th }}$ inter-node was for Sangh Tarom with 40 bushes per $\mathrm{m}^{2}$ and minimum of it were for local Tarom and Dilamani Tarom with 80 bushes per $\mathrm{m}^{2}$.

Islam and et al. (2007) reported that length or height of stem had a positive coefficient with diagonal of $4^{\text {th }}$ 
inter-node, length of inter-nodes $1^{\text {st }}, 2$ nd, $3 \mathrm{rd}$, and $4^{\text {th }}$ and Lodging resistance of $3^{\text {rd }}$ and $4^{\text {th }}$ inter-nodes, but it had not significantly correlation with weight of dry matter, Stem tension to lodging and lodging index of $3^{\text {rd }}$ and $4^{\text {th }}$ inter-nods.

\subsection{Effect of variety and interaction of variety $\times$ plant density on Lodging resistance in $3^{\text {rd }}$ and $4^{\text {th }}$ inter-nodes}

Lodging resistance in $3^{\text {rd }}$ and $4^{\text {th }}$ inter-nodes under the effect of variety and interaction effects of variety $\times$ plant density showed an extreme significant difference, as the maximum Lodging resistance of $3^{\text {rd }}$ and $4^{\text {th }}$ inter-nodes was for Langhrodi Tarom, but minimum of it in $3^{\text {rd }}$ inter-node was for Hashemi Tarom and for $4^{\text {th }}$ inter-node was for Hashemi Tarom and Dilamani Tarom. While, plant density had not significantly effect on the Lodging resistance of the $3^{\text {rd }}$ and $4^{\text {th }}$ inter-nodes, but maximum of Lodging resistance was seen in $3^{\text {rd }}$ inter-node with 120 bushes per $\mathrm{m}^{2}$ and for $4^{\text {th }}$ inter-node was with 80 bushes per $\mathrm{m}^{2}$ (table 5 ).

As it is clear in table 7, maximum Lodging resistance was for the $3^{\text {rd }}$ inter-node under interaction effects for Langhrodi Tarom with 120 bushes per $\mathrm{m}^{2}$, and minimum of it was for Dilamani Tarom with 120 bushes per $\mathrm{m}^{2}$, Maximum of Lodging resistance in $4^{\text {th }}$ inter-node was for Langhrodi Tarom with 120 bushes per $\mathrm{m}^{2}$ and minimum of it was for Hashemi Tarom with 120 bushes per $\mathrm{m}^{2}$. Maximum Lodging resistance of $3^{\text {rd }}$ and $4^{\text {th }}$ inter-nodes sequentially were for SL-9H and SL-10H hybrids and minimum lodging index of $3^{\text {rd }}$ and $4^{\text {th }}$ inter-nodes came for IR72. Length of stem and leaf area index in hybrid rice may have effect on the increasing of Stem tension to lodging and consequently it increases the lodging index (Laza et al., 2001). By deduction of panicle number per bush some characteristics like Lodging resistance and lodging index have not got make bigger changes (Vojdani, 2006). Youshinaga (2005) found that by increasing of plant density from 40 into 160 bushes per $\mathrm{m}^{2}$ the height of stem was decreased, also lodging index by increasing of plant density increased, but Lodging resistance decreased.

Morphologic characteristics of lodging index was only measured for $3^{\text {rd }}$ and $4^{\text {th }}$ inter-nodes, because lodging of stem took place in low inter-nodes (Hoshikawa and Wang, 1990; Seko, 1962). Morphological characteristics have significantly correspondence between $3^{\text {rd }}$ and $4^{\text {th }}$ inter-nodes; therefore Lodging resistance and lodging index of these inter-nodes are important in lodging matter (Islam et al., 2007).

3.4 Effects of Variety, plant density and their interaction on the Stem tension to lodging of $3^{\text {rd }}$ and $4^{\text {th }}$ inter-nodes Variety, plant density and their interaction effects has had significantly effect on the Stem tension to lodging of $3^{\text {rd }}$ and $4^{\text {th }}$ inter-nodes (table 4). Maximum Stem tension to lodging was for $3^{\text {rd }}$ inter-node in Hashemi Tarom and Dilamani Tarom. Maximum of Stem tension to lodging in $4^{\text {th }}$ inter-node also was seen in Hashemi Tarom and minimum of it was for Dilamani Tarom. In table 5 can see that Stem tension to lodging of the $3^{\text {rd }}$ inter-node under the various plant density by increasing of it from 40 bushes up to 120 bushes per $\mathrm{m}^{2}$ had $20.1 \%$ deduction and minimum Stem tension to lodging was for the $4^{\text {th }}$ inter-node with 120 bushes per $\mathrm{m}^{2}$. Maximum Stem tension to lodging under the interaction effects of variety $\times$ plant density was for Hashemi Tarom with 40 bushes per $\mathrm{m}^{2}$ and minimum of that was for Dilamani Tarom with 80 bushes per $\mathrm{m}^{2}$. Minimum Stem tension to lodging of $4^{\text {th }}$ inter-node for various varieties was local Tarom with 120 bushes per $\mathrm{m}^{2}$, but minimum of it in 80 bushes per $\mathrm{m}^{2}$ was for Dilamani Tarom (table 7).

3.5 The effect of variety and interaction effects of variety $\times$ plant density on Lodging index of $3^{\text {rd }}$ and $4^{\text {th }}$ inter-nodes

Lodging index of $3^{\text {rd }}$ and $4^{\text {th }}$ inter-nodes was experimented from statistical point of view under the variety and interaction effects of variety $\times$ plant density in $1 \%$ probability level. Effects of plant density had significantly affect on lodging index of $3^{\text {rd }}$ and $4^{\text {th }}$ inter-node in $5 \%$ and $1 \%$ probability levels respectively (table 4$)$. Minimum lodging index of $3^{\text {rd }}$ and $4^{\text {th }}$ inter-node in Langhrodi Tarom and maximum of it has seen in Hashemi Tarom.

Minimum lodging index of $3^{\text {rd }}$ and $4^{\text {th }}$ inter-nodes was for 80 bushes per $\mathrm{m}^{2}$ (table 5). Maximum lodging index for $3^{\text {rd }}$ and $4^{\text {th }}$ inter-nodes was in Hashemi Tarom with 40 and 120 bushes per $\mathrm{m}^{2}$ and minimum lodging index of $3^{\text {rd }}$ and $4^{\text {th }}$ inter-nodes in Langhrodi Tarom was with 120 bushes per $\mathrm{m}^{2}$ (table 7 ).

Islam et al. (2007) found that lodging morphological of characteristics are different between hybrids and hybrid-less varieties and it changes from $14 \mathrm{~mm}$ to $26 \mathrm{~mm}$ among the characteristics of $4^{\text {th }}$ inter-node diagonal among the various genotypes of rice and respectively is IR79172H and Sl-11H fro hybrids. Minimum plan height was $93 \mathrm{~cm}$ for Indica genotypes IR72 and maximum of it was $129 \mathrm{~cm}$ for BRRI Dhan $1 \mathrm{H}$.

\section{Conclusions}

According to the research results, as the total number of tiller and effective tiller per bush reduces by plant density deduction, but the number of panicle per $\mathrm{M}^{2}$ has had a significantly increasing. Also, length of panicle and flag leaf by increasing of plant density had deduction, but the total number of spikelet, hollow spikelet per panicle, weight of 1000-seed and straw yield under the plant density effects have not shown significant differences.

Although, plant density has not had significantly effect on plant height, length of $4^{\text {th }}$ inter-node, Lodging resistance of $3^{\text {rd }}$ and $4^{\text {th }}$ inter-nodes, but by increasing of plant density, Stem tension to lodging of $3^{\text {rd }}$ and $4^{\text {th }}$ inter-nodes was deduced, because minimum number of inter-node and length of $3^{\text {rd }}$ inter-node was reduced in 
120 bushes per $\mathrm{m}^{2}$. Plant height had not significantly deduction by increasing of bush number per $\mathrm{M}^{2}$.

On the other hand, maximum Stem tension to lodging of $3^{\text {rd }}$ inter-node came in minimum plant density because maximum number of inter-node and maximum length of $3^{\text {rd }}$ inter-node was seen in 40 bushes per $\mathrm{M}^{2}$. In other words, length of $1^{\text {st }}, 2^{\text {nd }}$, and $3^{\text {rd }}$ inter-nodes and number of inter-nodes by increasing of plant density had extreme deduction and the reason of this matter was because of bushes competitions for assimilation of food materials. Also, decrease of lodging index especially Stem tension to lodging of $3^{\text {rd }}$ and $4^{\text {th }}$ inter-nodes in a high plant density was not an exception to the matter.

\section{References}

Baloch, A.W., A.M. Soomro, M.A. Javed, M. Ahmed, H.R. Bughio, M.S. Bughio and N.N. Mastoi. (2002). Optimum plant density for high yield in rice (Oryza sativa L.). Asian J. Plant Sci., 1: 25-27. http://dx.doi.org/10.3923/ajps.2002.25.27

Chandler, R.F.Jr. (1969). Plant morphology and stand geometry in relation to nitrogen. Pp 265-285. In Physiological aspects of crop yield. J. D. Eastin, F.A. Haskin, C.Y. Sullivan and C.H.M. Van Baul, eds. ASA Publication, Madison, Wisconsin.

Chang, T.T. (1964). Varietal differences in lodging resistance. Int. Rice Comm. Newsl, 13 (4).1-11.

Chang TT, Vergara BS. (1972). Ecological and genetic information on adaptability and yielding ability in tropical rice varieties. In: Rice Breeding, pp. 431-453. International Rice Research. Institute, Los Banos, Philippines (1972).

Dunald, R.R, Dilly. (1982). Rice growth analysis. 7th Annual progress report rice experiment station Crowely. Louisana, 159-172.

Flintham, J.E., A. Boerner, A.J. Worland, and M.D. Gale. (1997). Optimizing wheat grain yield: Effects of Rht (gibberellin-insensitive) dwarfing genes. J. Agric. Sci., (Cambridge) 128, 11-25.

Gent, M.P.N. (1995). Canopy light interception, gas exchange, and biomass in reduced height isolines of winter wheat. Crop Sci., 35:1636-1642. http://dx.doi.org/10.2135/cropsci1995.0011183X003500060020x

Hadji Christodoulou, A. (1991). The relationship of grain yield with harvest index and total biological yield of barely in dryland technical bulletin No.126. Agricultural Institute. Nicosia, Gyprus.

Hamidul Islam, Md. and S.M. Altaf Hossain. (2002). Effect of fertilization and planting density on the yield of two varieties of fine rice. Pak. J. Biol. Sci., 5: 513-516. http://dx.doi.org/10.3923/pjbs.2002.513.516

Hitaka, H. and Kobayashi, H. (1961). Studies on the lodging of rice plants. (II) Source of decreasing yield due to lodging. Japanese Journal of Crop Science, 32: 270-276. http://dx.doi.org/10.1626/jcs.32.270

Hoshikawa K, Wang S B. (1990). Studies on lodging in rice plant. Jpn J Crop Sci, 59(4): 809-814. http://dx.doi.org/10.1626/jcs.59.809

Islam MS, Peng S, Visperas RM, Ereful N, Bhuiya MSU, Julfiquar AW. (2007). Lodging-related morphological traits of hybrid rice in a tropical irrigated ecosystem.

Kashiwagi, T., H. Sasaki, K. Ishimaru. (2005). Factors responsible for decreasing sturdiness of the lower part in lodging of rice (Oryza sativa). Plant Prod.Sci., 8:166-172. http://dx.doi.org/10.1626/pps.8.166

Kono M. (1995). Physiological aspects of lodging. In T Matsuo, K Kumazawa, R Ishii, K Ishihara, H Hirata, eds, Science of the Rice Plant, Vol 2. Jpn J Crop Sci, 52: 7-14.

Kuroda, E., T. Ookawa, and K. Ishihara. (1989). Analysis on dry matter production between rice cultivars with different plant height in relation to gas diffusion inside stands. Jpn.

Laza, R.C., Peng, S., Sanico, A.L., Visperas, R.M., and Akita, S. (2001). Higher leaf area growth rate contributes to greater vegetative growth of F1 hybrids in the tropics. Plant Prod. Sci., 4:184-188. http://dx.doi.org/10.1626/pps.4.184

Mobasser H.M., and Mohseni Delarestaghi, M., Khorgami, A., Barari Tari D. and Pourkalhor H. (2007). Effect of planting density on agronomical characteristics of rice (Oryza sativa L.) Varieties in North of Iran. Pakistan Journal of Biological Sciences, 10.

Ookawa T, Ishihara K. (1992). Varietal difference of physical characteristics of the culm related to lodging resistance in paddy rice. Jpn J Crop Sci, 61: 419-425. http://dx.doi.org/10.1626/jcs.61.419

Seko H. (1962). Studies on lodging in rice plants. Bull Kyusyu Agric Exp Stn, 1962, 7: 419-499.

Setter, T.L., Laureles, E.V. and Mazaredo, A.M. (1997). Lodging reduces yield of rice by self-shading and reductions in canopy photosynthesis. Field Crops Research, 49: 95-106. http://dx.doi.org/10.1016/S0378-4290(96)01058-1

Tang, W. and WU. Qingfa. (2000). Effect of sowing density and fertilizer application on hybrid carly rice cultivar._Zhejiang Nongye Kexue, No. 6: 269-273. 
Terashima K, Ogata T, Akita S. (1994). Eco-physiological characteristics related with lodging tolerance of rice in direct sowing cultivation. II. Root growth characteristics of tolerant cultivars to root lodging. Jpn J Crop Sci, 63: 34-41. http://dx.doi.org/10.1626/jcs.63.34

Vojdani, M. (2006). Effect of planting-age and plant densityon agronomical characteristics of high product rice Neda variety. Islamic Azad University of mashhad. p.97.

Yoshinaga S. (2005). Improved Lodging Resistance in Rice (Oryza sativa L.) Cultivated by Submerged Direct Seeding Using a Newly Developed Bush Seeder. Journal Title; JARQ. Journal Code: Y0175A. ISSN:0021-3551. VOL.39; NO.3; PAGE. 147-152.

Zuber, U., Winzeler, H., Messer, M.M., Keller, B., Schimd, J.F., Stamp, P. (1999). Morphological traits associated with lodging resistance of spring wheat (Triticum aestivun L.). J. Agron Crop Sci., 182, 17-24. http://dx.doi.org/10.1046/j.1439-037x.1999.00251.x

\section{$\mathrm{V} 1=$ local tarom \\ $\mathrm{V} 2=$ hashemi tarom \\ V3=dilamani tarom \\ V4=langhrodi taron \\ $\mathrm{V} 5=$ sangh tarom}

Planting- density

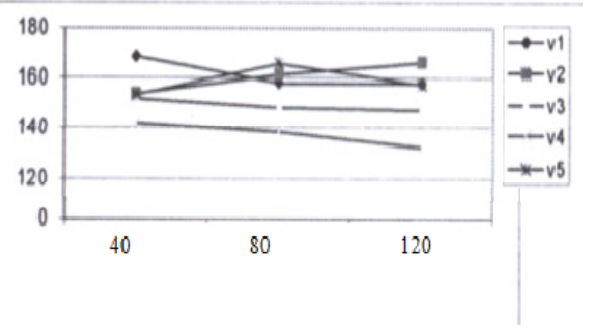

40

80

120

Diagram 1. Interaction effects of variety $\times$ plant density on plant height

Table 1. Sum of squares plant height and grain yield and yield components under plant-spacing in five variety

\begin{tabular}{|c|c|c|c|c|c|c|c|c|}
\hline Various source & $\mathrm{DF}$ & $\begin{array}{l}\text { Plant } \\
\text { height } \\
(\mathrm{cm})\end{array}$ & $\begin{array}{l}\text { Number } \\
\text { of tiller in } \\
\text { bush }\end{array}$ & $\begin{array}{l}\text { Total number } \\
\text { of spike-let per } \\
\text { panicle }\end{array}$ & $\begin{array}{c}\text { number of } \\
\text { hollow spike-let } \\
\text { per panicle }\end{array}$ & $\begin{array}{c}\text { number of } \\
\text { panicle in } \\
\mathrm{m}^{2}\end{array}$ & $\begin{array}{c}\text { Weight of } \\
\text { 1000-grain(gram) }\end{array}$ & $\begin{array}{l}\text { Grain yield } \\
\left(\mathrm{gr} / \mathrm{m}^{2}\right)\end{array}$ \\
\hline Replication & 3 & $59 / 52 *$ & $3 / 15^{*}$ & $451 / 88$ & $6 / 15$ & $10058 / 44^{* *}$ & $1 / 02$ & $9060 / 99 * *$ \\
\hline Variety & 4 & $1249 / 19 * *$ & $12 / 07 * *$ & $1388 / 23 * *$ & $1012 / 79 * *$ & $1567 / 30 * *$ & $23 / 2 * *$ & $203837 / 55^{* *}$ \\
\hline Error A & 12 & $6 / 73$ & $0 / 82$ & $245 / 18$ & $3 / 72$ & $555 / 58$ & $2 / 91$ & $1229 / 04$ \\
\hline Planting-density & 2 & $24 / 86$ & $57 / 97 * *$ & $127 / 77$ & $4 / 72$ & $2382 / 45^{* *}$ & $2 / 27$ & $8009 / 51 * *$ \\
\hline Variety $\times$ planing-density & 8 & $133 / 99 * *$ & $4 / 94 * *$ & $798 / 02 * *$ & $30 / 94 * *$ & $308 / 67$ & $6 / 19 * *$ & $9334 / 87 * *$ \\
\hline Error & 30 & $15 / 27$ & $1 / 02$ & $202 / 51$ & $9 / 15$ & $160 / 85$ & $1 / 29$ & $494 / 11$ \\
\hline$\%$ C.V & - & $2 / 54$ & $16 / 16$ & $12 / 86$ & $21 / 57$ & $3 / 78$ & $4 / 15$ & $3 / 59$ \\
\hline
\end{tabular}

*,** respectively significant in 51 probability levels.

Table 2. Simple effects variety and planting-density on average of plant height, yield and its components

\begin{tabular}{|c|c|c|c|c|c|c|c|}
\hline Treatments & $\begin{array}{l}\text { Plant } \\
\text { height }(\mathrm{cm})\end{array}$ & $\begin{array}{l}\text { Number of } \\
\text { tiller in bush }\end{array}$ & $\begin{array}{ll}\text { Total number of } \\
\text { spike-let } \\
\text { panicle }\end{array}$ & $\begin{array}{l}\text { number of hollow } \\
\text { spike-let in } \\
\text { panicle }\end{array}$ & $\begin{array}{ll}\text { number } & \text { of } \\
\text { panicle } & \text { in } \\
\mathrm{m}^{2} & \end{array}$ & $\begin{array}{l}\text { Weight of } \\
1000 \text {-grain(gram) }\end{array}$ & $\begin{array}{l}\text { Grain } \\
\text { yield }(\mathrm{gr} / \\
\left.\mathrm{m}^{2}\right)\end{array}$ \\
\hline Varieties & & & & & & & \\
\hline Local tarom & $161 / 58 \mathrm{a}$ & $4 / 95 \mathrm{c}$ & $122 / 9 \mathrm{a}$ & $9 / 63 \mathrm{c}$ & $315 / 08 \mathrm{~b}$ & $28 / 2 b$ & $732 / 5 \mathrm{a}$ \\
\hline Hashemi tarom & $160 / 58 \mathrm{ab}$ & $7 / 38 \mathrm{a}$ & $112 / 3 \mathrm{a}$ & $14 / 47 \mathrm{~b}$ & $321 / 33 \mathrm{~b}$ & $25 \mathrm{~b}$ & $461 / 5 \mathrm{~d}$ \\
\hline Dilamani tarom & $149 / 33 \mathrm{c}$ & $7 / 12 \mathrm{a}$ & $112 / 3 \mathrm{a}$ & $10 / 08 \mathrm{c}$ & $380 / 42$ a & $26 / 8$ a & $647 / 08 \mathrm{~b}$ \\
\hline Langhrodi tarom & $137 / 58 \mathrm{~d}$ & $5 / 81 \mathrm{~b}$ & $93 / 2 \quad b$ & $6 / 33 d$ & $365 / 08 \mathrm{a}$ & $28 / 2 a$ & $744 / 58 \mathrm{a}$ \\
\hline Sangh tarom & $159 / 0 \mathrm{~b}$ & $5 / 92 \mathrm{~b}$ & $112 / 3 \mathrm{a}$ & $29 / 62 \mathrm{a}$ & $294 / 08 \mathrm{c}$ & $28 / 2 \mathrm{a}$ & $501 / 92 \mathrm{c}$ \\
\hline Planting-density & & & & & & & \\
\hline 40 bushes per $\mathrm{m}^{2}$ & $154 / 5 \mathrm{a}$ & $7 / 76 \mathrm{a}$ & $113 / 1 \mathrm{a}$ & $14 / 52 \mathrm{a}$ & $301 / 95 \mathrm{c}$ & $27 / 6 \mathrm{a}$ & $627 / 25 \mathrm{a}$ \\
\hline 80 bushes per $\mathrm{m}^{2}$ & $154 / 4 \mathrm{a}$ & $6 / 55 \mathrm{~b}$ & $110 / 6 \mathrm{a}$ & $14 / 01 \mathrm{a}$ & $332 / 8 \quad b$ & $27 / 2 \mathrm{a}$ & $630 / 8$ a \\
\hline 120 bushes per $\mathrm{m}^{2}$ & $152 / 3 \mathrm{a}$ & $6 / 4 c$ & $108 / 09 \mathrm{a}$ & $13 / 55 \mathrm{a}$ & $370 / 85 \mathrm{a}$ & $27 / 0 \mathrm{a}$ & $594 / 5 \mathrm{a}$ \\
\hline
\end{tabular}

Averages with same words in every column according to Duncan test have not significantly difference in a 5 probability level

Table 3 . Effects of interaction variety $\times$ planting-density on rice grain yield and some of yield components

\begin{tabular}{|c|c|c|c|c|}
\hline \multicolumn{2}{|c|}{ Variety $\times$ planting-density } & Total number of tiller per bush & Number of panicle per $\mathrm{m}^{2}$ & Grain yield $\left(\mathrm{gr} / \mathrm{m}^{2}\right)$ \\
\hline $\begin{array}{l}40 \text { bushes per } \mathrm{m}^{2} \\
80 \text { bushes per } \mathrm{m}^{2} \\
120 \text { bushes per } \mathrm{m}^{2}\end{array}$ & Local tarom & $\begin{array}{l}6 / 75 \mathrm{~cd} \\
4 / 5 \mathrm{fg} \\
3 / 62 \mathrm{~g}\end{array}$ & $\begin{array}{c}273 / 75 \mathrm{hi} \\
308 / 5 \mathrm{~g} \\
363 \mathrm{~cd}\end{array}$ & $\begin{array}{c}772 / 5 \mathrm{a} \\
684 / 25 \mathrm{c} \\
740 / 75 \mathrm{ab}\end{array}$ \\
\hline $\begin{array}{l}40 \text { bushes per } \mathrm{m}^{2} \\
80 \text { bushes per } \mathrm{m}^{2} \\
120 \text { bushes per } \mathrm{m}^{2}\end{array}$ & Hashemi tarom & $\begin{array}{l}8 / 83 \mathrm{ab} \\
7 / 99 \mathrm{bc} \\
5 / 33 \mathrm{def}\end{array}$ & $\begin{array}{l}278 / 75 \mathrm{hi} \\
324 / 75 \mathrm{fg} \\
360 / 5 \mathrm{~d}\end{array}$ & $\begin{array}{c}453 / 0 \mathrm{f} \\
500 / 75 \mathrm{e} \\
430 / 75 \mathrm{f}\end{array}$ \\
\hline $\begin{array}{l}40 \text { bushes per } \mathrm{m}^{2} \\
80 \text { bushes per } \mathrm{m}^{2} \\
120 \text { bushes per } \mathrm{m}^{2}\end{array}$ & Dilamani tarom & $\begin{array}{r}9 / 5 \mathrm{a} \\
6 / 5 \mathrm{a} \\
5 / 37 \mathrm{de}\end{array}$ & $\begin{array}{l}351 \text { de } \\
381 / 0 \mathrm{bc} \\
409 / 25 \mathrm{a}\end{array}$ & $\begin{array}{l}658 / 75 \mathrm{c} \\
728 / 75 \mathrm{~b} \\
553 / 75 \mathrm{~d}\end{array}$ \\
\hline $\begin{array}{l}40 \text { bushes per } \mathrm{m}^{2} \\
80 \text { bushes per } \mathrm{m}^{2} \\
120 \text { bushes per } \mathrm{m}^{2}\end{array}$ & Langhrodi tarom & $\begin{array}{l}5 / 62 \text { de } \\
8 / 0 \text { bc } \\
3 / 81 \text { g }\end{array}$ & $\begin{array}{c}338 / 5 \text { ef } \\
363 / 5 \mathrm{~cd} \\
393 / 25 \mathrm{ab}\end{array}$ & $\begin{array}{c}737 / 0 \mathrm{~b} \\
754 / 5 \mathrm{ab} \\
742 / 25 \mathrm{ab}\end{array}$ \\
\hline $\begin{array}{l}40 \text { bushes per } \mathrm{m}^{2} \\
80 \text { bushes per } \mathrm{m}^{2} \\
120 \text { bushes per } \mathrm{m}^{2}\end{array}$ & Sangh tarom & $\begin{array}{l}8 / 12 \mathrm{abc} \\
5 / 75 \mathrm{de} \\
3 / 87 \mathrm{fg}\end{array}$ & $\begin{array}{l}267 / 75 \mathrm{i} \\
286 / 25 \mathrm{~h} \\
328 / 25 \mathrm{f}\end{array}$ & $\begin{array}{l}515 \text { e } \\
485 / 75 \mathrm{e} \\
505 \mathrm{e}\end{array}$ \\
\hline
\end{tabular}

Averages with same words in every column according to Duncan's multiple range test have not significantly difference in a 5\% probability level 
Table 4. Sum squares morphological characteristics that related to lodging under plant density in different rice varieties

\begin{tabular}{|c|c|c|c|c|c|c|c|c|c|c|c|c|c|c|}
\hline Various source & $\mathrm{DF}$ & LN1 & LN2 & LN3 & LN4 & $\mathrm{n} . \mathrm{N}$ & DN3 & DN4 & BR3 & BR4 & BM3 & BM4 & LI3 & LI4 \\
\hline Replication & 3 & $6 / 89$ & $3 / 85$ & $2 / 37$ & $5 / 43$ & $0 / 33^{* *}$ & $1 / 83^{* *}$ & $1 / 35^{* *}$ & $1 / 93^{* *}$ & $3 / 89$ & $165879 / 83^{* *}$ & $196087 / 08^{* *}$ & $3460 / 37$ & $2269 / 14$ \\
\hline Variety & 4 & $306 / 53 * *$ & $104 / 29^{* *}$ & $23 / 15^{* *}$ & $93 / 69 * *$ & $5 / 13^{* *}$ & $2 / 32 * *$ & $3 / 72 * *$ & $117 / 79 * *$ & $159 / 88^{* *}$ & $691322 / 42^{* *}$ & $880235 / 23 * *$ & $142299 / 24 * *$ & $104349 / 63 * *$ \\
\hline Error A & 12 & $11 / 007$ & $2 / 48$ & $2 / 57$ & $4 / 24$ & $0 / 37$ & $0 / 66$ & $0 / 81$ & $0 / 43$ & $3 / 17$ & $67306 / 13$ & $133798 / 44$ & $2788 / 01$ & $1927 / 35$ \\
\hline Planting-density & 2 & $35 / 12 * *$ & $40 / 28^{* *}$ & $29 / 09^{* *}$ & $8 / 79$ & $0 / 32^{* *}$ & $0 / 24 * *$ & $1 / 94 * *$ & $0 / 98$ & $5 / 1$ & $477552 / 81^{* *}$ & $690550 / 51^{* *}$ & $5495 / 29^{*}$ & $9895 / 51^{* *}$ \\
\hline Variety $\times$ plant density & 8 & $46 / 06^{* *}$ & $19 / 85^{* *}$ & $12 / 68^{*}$ & $32 / 27^{* *}$ & $0 / 03$ & $0 / 54 * *$ & $0 / 78^{* *}$ & $42 / 81^{* *}$ & $37 / 73^{* *}$ & $114834 / 19^{* *}$ & $202057 / 87^{* *}$ & $29190 / 78^{* *}$ & $6041 / 91^{* *}$ \\
\hline Error B & 20 & $5 / 75$ & $4 / 48$ & $4 / 38$ & $5 / 001$ & $0 / 03$ & $0 / 05$ & $0 / 19$ & $0 / 33$ & $2 / 06$ & $15475 / 47$ & $40630 / 22$ & $1619 / 36$ & $1092 / 89$ \\
\hline C.V & - & $5 / 49$ & $6 / 69$ & $7 / 55$ & $11 / 04$ & $4 / 12$ & $4 / 09$ & $6 / 58$ & $8 / 85$ & $14 / 38$ & $9 / 06$ & $10 / 50$ & $15 / 44$ & $14 / 85$ \\
\hline
\end{tabular}

$*, * *$ sequentially significant in 5,1 probability levels.

LN1, 2, 3, 4=length of inter-nodes 1, 2, 3, 4(CM) BM3, 4=Stem tension to lodging of inter-node 3, 4(gr/cm) n.N=inter-node number

DN3, 4=diagonal of inter-node 3, 4(MM) BR 3, 4=Lodging resistance of inter-node 3, 4(gram/stalk) $\quad$ LI 3, 4=lodging index of inter-node

Table 5. Effects of variety and plant density on morphological characteristics that related to lodging in rice

\begin{tabular}{|c|c|c|c|c|c|c|c|c|c|c|c|c|c|}
\hline \multirow[t]{2}{*}{ Treatments } & \multicolumn{4}{|c|}{ Inter-node length } & $\begin{array}{l}\text { Inter- } \\
\text { node }\end{array}$ & \multicolumn{3}{|c|}{ Inter-node diagonal } & \multicolumn{4}{|c|}{$\begin{array}{l}\text { lodging resistance inter-node bending } \\
\text { lodging Movement }(\mathrm{gr} / \mathrm{cm})\end{array}$} & $\begin{array}{l}\text { nter- node } \\
\text { index }(\%)\end{array}$ \\
\hline & 1 & 2 & 3 & & Number & 3 & 4 & 3 & 4 & 3 & 4 & 3 & 4 \\
\hline Varic & & & & & & & & & & & & & \\
\hline Hashemi tarom & $51 / 45 \mathrm{a}$ & $35 / 75 a$ & $28 \mathrm{a}$ & $17 / 09 \mathrm{c}$ & $4 / 82 a$ & $5 / 91 b c$ & $6 / 76 \mathrm{ab}$ & $4 / 2 d$ & $6 / 32 \mathrm{c}$ & $1723 / 4 a$ & $2311 / 9 a$ & $417 / 25 \mathrm{a}$ & $371 / 75 a$ \\
\hline Dilamani tarom & $44 \mathrm{~b}$ & $30 / 92 \mathrm{c}$ & $28 / 29 \mathrm{a}$ & $19 / 35 b$ & $4 / 62 \mathrm{a}$ & $5 / 36 b c$ & $5 / 87 \mathrm{c}$ & $5 / 22 \mathrm{c}$ & $7 / 51 \mathrm{c}$ & $1102 / 7 \mathrm{c}$ & $1642 / 1 \mathrm{c}$ & $233 / 58 b$ & $223 / 83 b$ \\
\hline Langhrodi tarom & $38 / 91 \mathrm{c}$ & $27 / 75 d$ & $24 / 84 b$ & $18 / 58 \mathrm{ba}$ & $3 / 45 b$ & $6 / 21 \mathrm{a}$ & $6 / 66 a b c$ & $12 \mathrm{a}$ & $15 / 79 a$ & $1200 / 9 b c$ & $1687 / 3 c$ & $112 / 9 \mathrm{c}$ & $114 / 86 c$ \\
\hline $\begin{array}{l}\text { Sangh tarom } \\
\text { Planting-density }\end{array}$ & $44 / 29 b$ & $30 / 87 \mathrm{c}$ & $28 / 81 \mathrm{a}$ & $22 / 31 \mathrm{a}$ & $3 / 43 b$ & $6 / 1 \mathrm{ab}$ & $7 / 36 \mathrm{a}$ & $6 / 11 b$ & $10 / 18 b$ & $1438 / 8 b$ & $2008 / 6 a b$ & $259 / 67 b$ & $204 / 08 b$ \\
\hline 40 bushs in $\mathrm{m}^{2}$ & $44 / 92 a$ & $32 / 97 \mathrm{a}$ & $29 / 04 a$ & $20 / 99 a$ & $4 / 23 a$ & $5 / 83 a$ & $6 / 93 a$ & $6 / 54 \mathrm{ab}$ & $10 / 05 \mathrm{ab}$ & $1530 / 4 a$ & $2084 / 2 a$ & $269 / 55 a$ & $224 / 05 a$ \\
\hline 80 bushs in $\mathrm{m}^{2}$ & $42 / 27 b$ & $31 / 8 \mathrm{a}$ & $26 / 69 b$ & $20 / 03 a$ & $4 / 17 \mathrm{a}$ & $5 / 64 b$ & $6 / 49 b$ & $6 / 31 b$ & $10 / 46 a$ & $1366 / 4 b$ & $1954 / 25 a$ & $241 / 4 b$ & $199 / 65 b$ \\
\hline 120 bushs in $\mathrm{m}^{2}$ & $43 / 62 \mathrm{ab}$ & $30 / 15 b$ & $27 / 41 b$ & $19 / 72 a$ & $3 / 99 b$ & $5 / 83 \mathrm{a}$ & $6 / 33 b$ & $6 / 75 a$ & $9 / 46 b$ & $1221 / 55 \mathrm{c}$ & $1717 / 7 \mathrm{~b}$ & $270 / 64 a$ & $244 / 07 a$ \\
\hline
\end{tabular}

Averages with same words in every column according to Duncan's multiple range test have not significantly difference in a $5 \%$ probability level

Table 6. Effects of interaction variety $\times$ plant density on morphological characteristics that related to lodging in rice

\begin{tabular}{|c|c|c|c|c|c|c|c|}
\hline \multirow{2}{*}{\multicolumn{2}{|c|}{ Variety $\times$ planting-density }} & \multicolumn{3}{|c|}{ Inter-node length $(\mathrm{cm})$} & \multicolumn{3}{|c|}{ inter-node diagonal $(\mathrm{mm})$} \\
\hline & & 1 & 2 & 3 & 4 & 3 & 4 \\
\hline \multirow{3}{*}{ Local tarom } & 40 bushes per $\mathrm{m}^{2}$ & $37 / 25 \mathrm{gb}$ & $32 / 5 \quad b$ & $31 / 25 \mathrm{a}$ & $27 / 6 \mathrm{a}$ & $5 / 44 \mathrm{~g}$ & $7 / 06 \mathrm{abc}$ \\
\hline & 80 bushes per $\mathrm{m}^{2}$ & $39 / 37$ efg & $33 / 25 \mathrm{~b}$ & $27 / 5 \mathrm{cdef}$ & $20 / 6 \mathrm{cdef}$ & $4 / 57 \mathrm{~h}$ & $5 / 51 \mathrm{f}$ \\
\hline & 120 bushes per $\mathrm{m}^{2}$ & $41 / 50 \mathrm{def}$ & 33 & $27 / 12$ def & $23 / 5 \mathrm{bc}$ & $5 / 72 \mathrm{fg}$ & $6 / 25 \mathrm{de}$ \\
\hline \multirow{3}{*}{ hashemi tarom } & 40 bushes per $\mathrm{m}^{2}$ & $56 / 25 \mathrm{a}$ & 41 & $28 / 77$ a-f & $15 / 9 \mathrm{gh}$ & $5 / 8$ ef & $7 / 18 a b c$ \\
\hline & 80 bushes per $\mathrm{m}^{2}$ & $49 / 75 \mathrm{~b}$ & $33 / 37 b$ & $28 / 12 b-f$ & $18 / 87 \mathrm{fg}$ & $6 / 1$ a-e & $7 / 02 \mathrm{bc}$ \\
\hline & 120 bushes per $\mathrm{m}^{2}$ & $48 / 37 \mathrm{~b}$ & $32 / 87 \mathrm{~b}$ & $27 / 12$ def & $16 / 5 \mathrm{gh}$ & $5 / 58 \mathrm{def}$ & $6 / 08$ ef \\
\hline \multirow{3}{*}{ dilamani tarom } & 40 bushes per $\mathrm{m}^{2}$ & $48 / 75 \mathrm{~b}$ & $32 / 37 \mathrm{~b}$ & $30 / 62 \mathrm{ab}$ & $20 / 45$ cdef & $5 / 41 \mathrm{~g}$ & $5 / 95 \mathrm{ef}$ \\
\hline & 80 bushes per $\mathrm{m}^{2}$ & $38 / 5 \mathrm{fg}$ & $28 / 5 \mathrm{~cd}$ & $25 / 12 \mathrm{fg}$ & $18 / 87$ efg & $4 / 97 \mathrm{~h}$ & $5 / 60 \mathrm{f}$ \\
\hline & 120 bushes per $\mathrm{m}^{2}$ & $44 / 75 \mathrm{~cd}$ & $31 / 87 \mathrm{~b}$ & $29 / 12$ abcd & $18 / 75 \mathrm{fg}$ & $5 / 69 \mathrm{fg}$ & $6 / 08 \mathrm{ef}$ \\
\hline \multirow{3}{*}{ langhrodi tarom } & 40 bushes per $\mathrm{m}^{2}$ & $39 / 62$ efg & $27 / 62 \mathrm{~d}$ & $25 / 20 \mathrm{fg}$ & $18 / 75 \mathrm{fg}$ & $6 / 20 a b c$ & $6 / 79 \mathrm{~cd}$ \\
\hline & 80 bushes per $\mathrm{m}^{2}$ & $37 / 25 \mathrm{~g}$ & $26 / 87 d$ & $26 / 07$ efg & 22 bcde & $6 / 42 \mathrm{a}$ & $6 / 81 \mathrm{~cd}$ \\
\hline & 120 bushes per $\mathrm{m}^{2}$ & $39 / 87$ efg & $38 / 75 \mathrm{~cd}$ & $23 / 25 \mathrm{~g}$ & $15 \mathrm{~h}$ & $6 / 02 b-f$ & $6 / 38 \mathrm{de}$ \\
\hline \multirow{3}{*}{ sangh tarom } & 40 bushes per $\mathrm{m}^{2}$ & $42 / 75$ de & $31 / 37 b c$ & 29/37 abcd & $22 / 25 \mathrm{bcd}$ & $6 / 28 \mathrm{ab}$ & $7 / 68 \mathrm{a}$ \\
\hline & 80 bushes per $\mathrm{m}^{2}$ & $46 / 5 \mathrm{bc}$ & $28 / 75 \mathrm{~cd}$ & $26 / 62$ def & $19 / 8 \mathrm{def}$ & $6 / 14$ abcd & $7 / 54 \mathrm{ab}$ \\
\hline & 120 bushes per $\mathrm{m}^{2}$ & $43 / 62 \mathrm{~cd}$ & $32 / 5 \quad b$ & $30 / 45 \mathrm{abc}$ & $24 / 87 \mathrm{bc}$ & $5 / 88 \mathrm{cdef}$ & $6 / 86 \mathrm{~cd}$ \\
\hline
\end{tabular}

Averages with same words in every column according to Duncan's multiple range test have not significantly difference in a $5 \%$ probability level.

Table 7. Effects of interaction variety $\times$ plant density on lodging resistance, Stem tension to lodging and lodging index in rice

\begin{tabular}{|c|c|c|c|c|c|c|c|}
\hline \multirow{2}{*}{\multicolumn{2}{|c|}{ Variety $\times$ planting-density }} & \multicolumn{2}{|c|}{ Lodging resistance of inter-node } & \multicolumn{4}{|c|}{$\underline{\text { Stem tension to lodging of inter-node }(\mathrm{gr} / \mathrm{cm})}$ lodging index of inter-node $(\%)$} \\
\hline & & 3 & 4 & 3 & 4 & & 4 \\
\hline \multirow{4}{*}{ Local tarom } & 40 bushs in $\mathrm{m}^{2}$ & $6 / 82 \mathrm{de}$ & $11 / 02 \mathrm{c}$ & $1802 / 7 \mathrm{ab}$ & $2486 \quad \mathrm{a}$ & $267 / 2$ & $227 / 2$ def \\
\hline & 80 bushs in $\mathrm{m}^{2}$ & $4 / 18 \mathrm{fgh}$ & $11 / 68 \mathrm{bc}$ & $1324 / 7 \mathrm{de}$ & $1793 / 5$ cde & $326 \mathrm{~b}$ & $167 \mathrm{ghi}$ \\
\hline & 120 bushs in $\mathrm{m}^{2}$ & 4/37 fgh & $7 / 75 \mathrm{de}$ & $1067 \mathrm{gh}$ & $1551 / 7 \mathrm{e}$ & $244 / 5 \mathrm{~cd}$ & $201 \mathrm{efg}$ \\
\hline & 40 bushs in $\mathrm{m}^{2}$ & $3 / 68 \mathrm{hi}$ & $6 / 81 \mathrm{de}$ & $1967 \mathrm{a}$ & $2554 / 7 \mathrm{a}$ & $536 \mathrm{a}$ & $372 / 7 \mathrm{~b}$ \\
\hline \multirow[t]{3}{*}{ hashemi tarom } & 80 bushs in $\mathrm{m}^{2}$ & $4 / 78 \mathrm{fg}$ & $7 / 61 \mathrm{de}$ & $1745 / 7 b$ & $2413 \mathrm{ab}$ & $364 / 7 \mathrm{~b}$ & $317 / 7 \mathrm{c}$ \\
\hline & 120 bushs in $\mathrm{m}^{2}$ & $4 / 12 \mathrm{gh}$ & $4 / 55 \mathrm{f}$ & $1457 / 5 \mathrm{~cd}$ & $1968 \mathrm{bc}$ & $351 \mathrm{~b}$ & $324 / 7 \mathrm{a}$ \\
\hline & 40 bushs in $\mathrm{m}^{2}$ & $7 / 43 \mathrm{~d}$ & $8 / 43 \mathrm{~d}$ & $1174 / 2$ efgh & $1756 / 2 \mathrm{cde}$ & $158 \mathrm{ef}$ & $208 \mathrm{efg}$ \\
\hline \multirow[t]{3}{*}{ dilamani tarom } & 80 bushs in $\mathrm{m}^{2}$ & $5 / 0 \mathrm{f}$ & $8 / 28 d$ & $1016 / 5 \mathrm{~h}$ & $1573 / 7 \mathrm{e}$ & $201 / 7 \mathrm{de}$ & $189 / 7 \mathrm{fgh}$ \\
\hline & 120 bushs in $\mathrm{m}^{2}$ & $3 / 25 \mathrm{i}$ & $5 / 81$ ef & $1117 / 2 \mathrm{fgh}$ & $1596 / 2 \mathrm{de}$ & $341 \mathrm{~b}$ & $273 / 7 \mathrm{~cd}$ \\
\hline & 40 bushs in $\mathrm{m}^{2}$ & $8 / 44 b c$ & $13 / 47 b$ & $1172 / 7 \mathrm{fgh}$ & $1644 / 7 \mathrm{de}$ & $139 / 2 \mathrm{f}$ & $122 / 5 \mathrm{i}$ \\
\hline \multirow[t]{3}{*}{ langhrodi tarom } & 80 bushs in $\mathrm{m}^{2}$ & $9 / 21 b$ & $12 / 42 \mathrm{bc}$ & $1230 / 5$ efg & $1825 / 5 \mathrm{cde}$ & $133 / 7 \mathrm{f}$ & $147 / 7 \mathrm{hi}$ \\
\hline & 120 bushs in $\mathrm{m}^{2}$ & $18 / 37 \mathrm{a}$ & $21 / 47 \mathrm{a}$ & $1199 / 5$ efg & $1591 / 5$ de & $65 / 7 \mathrm{~g}$ & $74 / 3 \mathrm{j}$ \\
\hline & 40 bushs in $\mathrm{m}^{2}$ & $6 / 32 \mathrm{e}$ & $10 / 51 \mathrm{c}$ & $1535 / 25 \mathrm{c}$ & $1979 / 2 b c$ & $247 / 25 \mathrm{~cd}$ & $189 / 7 \mathrm{fgh}$ \\
\hline \multirow[t]{2}{*}{ sangh tarom } & 80 bushs in $\mathrm{m}^{2}$ & $8 / 37 b c$ & $12 / 32 \mathrm{bc}$ & $1514 / 5 \mathrm{c}$ & $2165 / 5 \mathrm{a}$ & $180 / 75$ ef & $176 \mathrm{gh}$ \\
\hline & 120 bushs in $\mathrm{m}^{2}$ & $3 / 65 \mathrm{hi}$ & $7 / 72 \mathrm{de}$ & $1266 / 5 \mathrm{ef}$ & $1881 \mathrm{bcd}$ & $351 \mathrm{~b}$ & $246 / 5 \mathrm{de}$ \\
\hline
\end{tabular}

Averages with same words in every column according to Duncan's multiple range test have not significantly difference in a $5 \%$ probability level. 